\title{
TYPE MATERIAL OF CHRYSANTHEMUM ZAWADZKII (ASTERACEAE) IN THE HUNGARIAN NATURAL HISTORY MUSEUM
}

\author{
K. Sutorý \\ Department of Botany, Moravian Museum \\ Hviezdoslavova 29a, CZ-629 00 Brno, Czech Republic; E-mail: ksutory@mzm.cz
}

(Received 20 October, 2014; Accepted 15 November, 2014)

\begin{abstract}
A new isoepitype of Chrysanthemum zawadzkii is reported from the higher plant collection of the Hungarian Natural History Museum, Budapest (BP).
\end{abstract}

Key words: Asteraceae, Carpathians, Chrysanthemum, Dendranthema, isoepitype

Chrysanthemum zawadzkii Herbich [= Dendranthema zawadzkii (Herbich) Tzvelev = Tanacetum zawadzkii (Herbich) Pawł.] was described from specimens collected in 1829 by Franz Herbich on the locality in the Polish Pieniny Mts in the Western Carpathians (Herbich 1831: 6, 44). Recently the circumstances of description and the typification of Chrysanthemum zawadzkii Herbich were published by Szelarg and Kobiv (2014). The icon in F. Herbich, Addit. ad Fl. Galic.: Tab. 1831 was determined as lectotype and the specimen from the locality "In cacumine montis Gacza Pienninorum. Circuli Sandecien[sis] Galiciae legit August 1832" Auctor [F. Herbich], which is deposited under LW 214045, was selected as epitype. Five isoepitypes were found, namely in BRNM s.n., LE s.n., LW 214046, W 1896-7789, and W Fenzl 0049071 (abbreviations are given according to Thiers 2008). The list of isoepitypes can be supplemented with a specimen deposited in the Hungarian Natural History Museum under number BP 495420. The label is written by Herbich and reads "In Sandecensi prope Kroscienki in rupibus calcareis montium Pienninorum in cacumine montis Kacza cum Spiraea chamadryfolia [sic!], legit Fr. Herbich". It is imprinted with a rubber stamp of the original owner of the specimen, Hungarian botanist and archbishop Lajos Haynald (Fig. 1). 


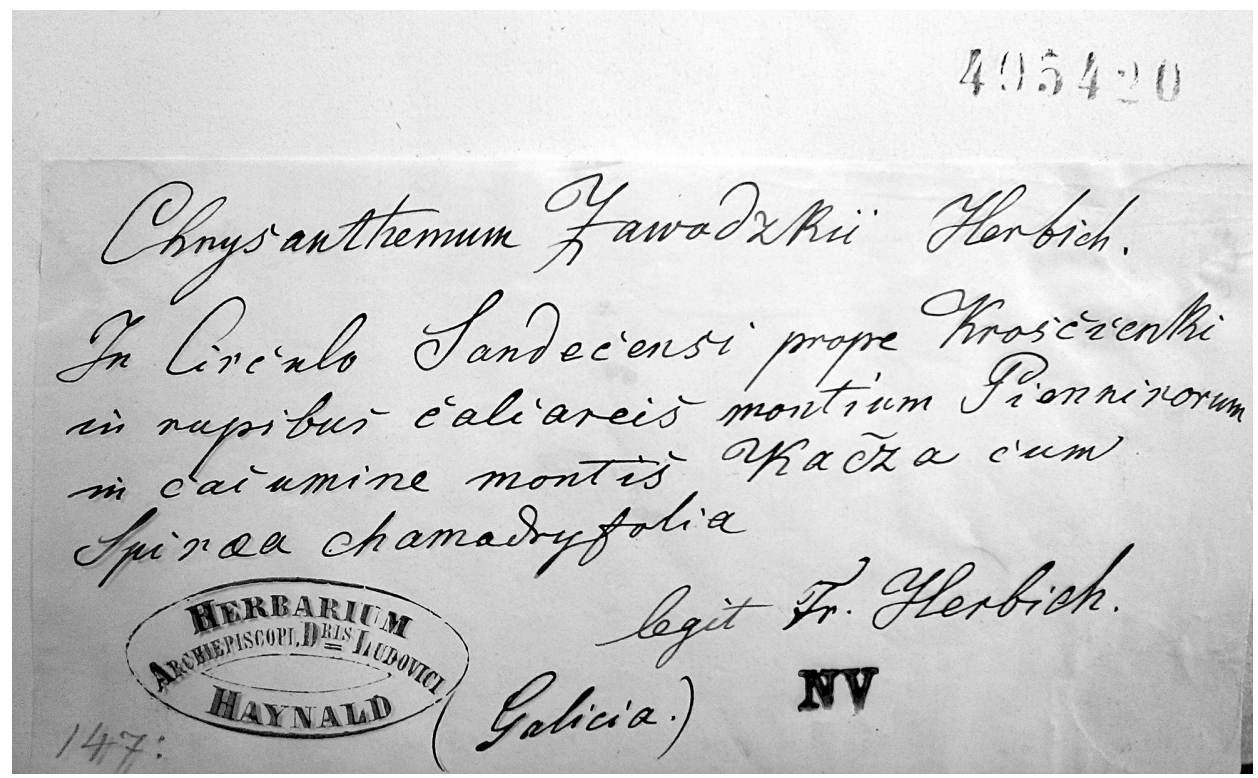

Fig. 1. Label of the Budapest specimen of Chrysanthemum zawadzkii Herbich. Although the text of labels on isotypes is not identical with the epitype, we can consider them as part of coincident collection. According to Herbich (1834: 573-574) the material was collected on 27th July 1832 during his second trip to the Pieniny Mts. on the "Berg Gacza" on its "kalkfelsigen Gipfeln"

Acknowledgements - My thanks are due to Zoltán Barina and Daniel Pifkó of the Hungarian Natural History Museum for enabling my work in the herbarium collections. This article appears through financial support provided to the Moravian Museum by the Ministry of Culture of the Czech Republic as part of its long-term conceptual development program for research institutions (ref. MK000094862).

\section{REFERENCES}

Herbich, F. (1831): Additamentum ad floram Galiciae. - Kuhn et Millikowski, Leopoli, Stanislavoviae et Tarnoviae et C. Wenzel, Przemysliae.

Herbich, F. (1834): Botanischer Ausflug in die galizisch-karpatischen Alpen des Sandezer Kreises. Flora 17(36): 561-575.

Szelagg, Z. and Kobiv, Y. (2014): Typification of Chrysanthemum zawadzkii (Asteraceae). Polish Bot. J. 59(1): 27-30. doi: 10.2478/pbj-2014-0005

Thiers, B. (2008) [continuously updated]: Index herbariorum: A global directory of public herbaria and associated staff. New York Botanical Garden: published at http://sciweb.nybg. org/science2/IndexHerbariorum.asp 